\title{
Two new species of Trouessartia Canestrini, 1899 (Astigmata: Trouessartiidae) from passeriform birds in Brazil
}

\author{
Fabio A. Hernandes
}

Received: 16 March 2017/Accepted: 1 September 2017/Published online: 11 October 2017

(C) Springer Science+Business Media B.V. 2017

\begin{abstract}
Two new feather mite species of the genus Trouessartia Canestrini, 1899 (Analgoidea: Trouessartiidae) are described from passerines (Aves: Passeriformes) in Brazil: T. calcealgiana n. sp. from Philydor atricapillus (Wied) (Furnariidae), and $T$. gigaphallus n. sp. from Tyrannus melancholicus Vieillot (Tyrannidae). Both species have unique features, such as the large hook-like seta $s R$ on trochanters III in T. calcealgiana, and the large male genitalia in $T$. gigaphallus, which are at least twice as long as normally found in most species of Trouessartia.
\end{abstract}

\begin{abstract}
This article was registered in the Official Register of Zoological Nomenclature (ZooBank) as 15B8AEB5-ED96-486E-9B5A31C79E445D50. This article was published as an Online First article on the online publication date shown on this page. The article should be cited by using the doi number. This is the Version of Record.
\end{abstract}

This article is part of the Topical Collection Arthropoda.

F. A. Hernandes $(\square)$

Departamento de Zoologia, Universidade Estadual

Paulista, Av. 24-A, 1515, Rio Claro,

São Paulo 13506-900, Brazil

e-mail: abakashi@gmail.com

\section{Introduction}

Feather mites of the family Trouessartiidae Gaud, 1957 (Astigmata: Analgoidea) are moderate-sized mites, mainly occupying the large wing and tail feathers (Mironov \& González-Acuña, 2013), but also occurring on the covert feathers of the head (Hernandes, 2015). From the 11 trouessartiid genera, three occur on birds of the Neotropical region: the monotypic Steatacarus Atyeo \& Peterson, 1977 from the oilbird Steatornis caripensis Humboldt (Caprimulgiformes), Calcealges Gaud, 1952, and Trouessartia Canestrini, 1899 (Atyeo \& Peterson, 1977; Gaud, 1952; Orwig, 1968; Gaud \& Atyeo, 1996). Species of Calcealges in the New World are predominantly associated with passerines of the family Thamnophilidae, with four described species and at least six undetermined species known up to this date (Hernandes, 2015; Barreto et al., 2012). Kanegae et al. (2008) also reported some undetermined species from birds of the family Parulidae, but these quite likely require confirmation. Trouessartia is represented in the Neotropics by nearly 20 described species associated with passerines of various families, in addition to one species from woodpeckers (Piciformes: Picidae) (Berla, 1959a, b, 1960, 1962; Černý \& Lukoschus, 1975; Mauri \& De Alzuet, 1968; Santana, 1976; OConnor et al., 2005; Valim et al., 2011; Mironov \& González-Acuña, 2013; Hernandes, 2014; Hernandes \& Valim, 2015; Hernandes \& OConnor, 2017). In this paper, two new species of Trouessartia are described 
from two species of suboscine passerines (Passeriformes) in Brazil.

\section{Materials and methods}

Most mites were collected from live birds captured with mist nets in the frame of a project surveying the ectoparasitic fauna of birds in the State of Paraná carried out during 1993; one specimen was collected from a roadkilled Tyrannus melancholicus (Tyrannidae) in Rio Claro, São Paulo State. The mites were picked from detached feathers under stereomicroscope, cleared in $30 \%$ lactic acid for $24 \mathrm{~h}$ at $50^{\circ} \mathrm{C}$, and mounted in Hoyer's medium (Krantz \& Walter, 2009). After five days at $50^{\circ} \mathrm{C}$, the slides were sealed with varnish.

Drawings and photomicrographs were made with a Leica DM3000 microscope equipped with differential interference contrast (DIC) optics and a camera lucida. Pencil sketches were scanned at 300 dpi grayscale and line drawings were created with Adobe Illustrator CS6 and a Wacom Bamboo Create tablet. The chaetotaxy of the idiosoma and legs follows Griffiths et al. (1990) and Atyeo \& Gaud (1966), respectively, with corrections of coxal setae proposed by Norton (1998). All measurements are in micrometres. The type-material is deposited at the Collection of Acari of Department of Zoology of the Universidade Estadual Paulista, Rio Claro, São Paulo, Brazil (accessions DZUnesp-RC \#3734-3750).

\section{Superfamily Analgoidea Trouessart \& Mégnin, 1884}

\section{Family Trouessartiidae Gaud, 1957}

Genus Trouessartia Canestrini, 1899

\section{Trouessartia calcealgiana $\mathbf{n}$. sp.}

Type-host: Philydor atricapillus (Wied) (Passeriformes: Furnariidae).

Type-locality: Ilha das Peças $\left(25^{\circ} 24^{\prime} \mathrm{S}, 48^{\circ} 17^{\prime} \mathrm{W}\right)$, Superagüi National Park, Paraná State, Brazil.

Type-material: Holotype male (DZ-UnespRC 3734), 26.xi.1993, coll. M. Arzua (ARM-1655, band \# E25410). Paratypes: 2 males and 4 females (DZUnespRC 3735-3740), same data as for the holotype. ZooBank registration: To comply with the regulations set out in article 8.5 of the amended 2012 version of the International Code of Zoological Nomenclature (ICZN, 2012), details of the new species have been submitted to ZooBank. The Life Science Identifier (LSID) for Trouessartia calcealgiana n. sp. is urn:1sid:zoobank.org:act:8CD4A771-D7A7-4E329E52-92D4AE4611FC.

Etymology: The epithet is derived from Calcealges, a trouessartiid genus with which this species superficially bears resemblance with regard to some characters, such as ambulacral discs of posterior legs much larger than those of anterior legs, posterior part of female opisthosoma elongate and gradually attenuate, and subhumeral seta $c 3$ with subapical tooth.

Description (Figs. 1-3, 7A-C)

Male [Holotype, range for 2 paratypes in parentheses.] Length of idiosoma from anterior extremity to bases of setae $h 3472$ (466-4,778), greatest width of idiosoma at level of humeral shields 219 (215-225). Length of hysterosoma from sejugal furrow to bases of setae $h 3$ 331 (330-343). Prodorsal shield: length along midline 119 (119-125), greatest width of posterior part 152 (152-155), lateral margins at level of trochanters II with shallow concavities, antero-lateral extensions rounded, not extending to bases of epimerites Ia between legs I and II, lateral margins of posterior part not fused with scapular shields, posterior margin straight, surface smooth (Fig. 1A). Vertical setae ve represented by alveoli. Internal scapular setae si thin needle-like, 26 (26) long, separated by 65 (63-68); external scapular setae se 174 (156-195) long, separated by 103 (99-104). Humeral shield with setae $c 2$ thick needle-like, 35 (34-36) long. Setae $c 3$ narrowly lanceolate, with subapical tooth, 29 (28-31) long. Prohysteronotal and lobar shields fused. Prohysteronotal shield: length 175 (172-176), width at anterior margin 157 (157-160), lateral margins with shallow incisions at level of trochanters III, dorsal hysterosomal apertures (DHA) absent, surface smooth (Fig. 1A). Dorsal setae $d 1, d 2$ present, minute. Setae $f 2$ absent. Length of lobar shield excluding lamellae 99 (99-105). Apical parts of opisthosomal lobes approximate, separated by narrow terminal cleft, length of cleft from anterior extremity to apices of lamellae 59 (59-63), width in anterior part 4 (3-4). Lamellae oblong in shape, rounded apically, margins smooth, length from bases of setae $h 3$ to lamellar apices 40 (38-44). Setae h2 284 (280-290) long, setae h3 213 


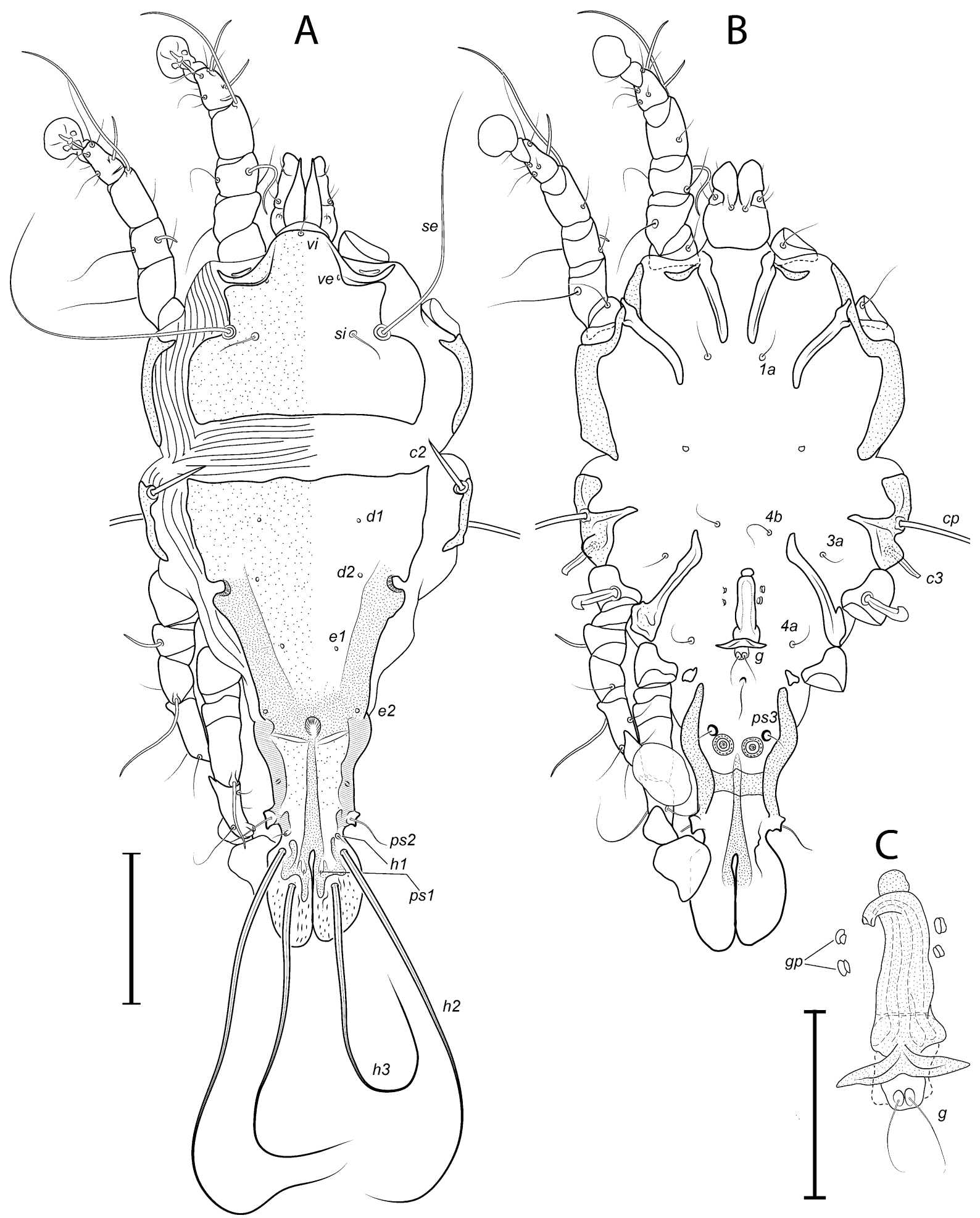

Fig. 1 Trouessartia calcealgiana n. sp. Male. A, Dorsal view; B, Ventral view; C, Genital apparatus. Abbreviation: gp, genital papillae. Scale-bars: A, B, $100 \mu \mathrm{m}$; C, $50 \mu \mathrm{m}$ 
(195-215) long. Distance between levels of dorsal setae and setal pairs: $c 2-d 255$ (50-56), $d 1-d 235$ (32-35), el-e2 42 (40-42), e2-h2 91 (90-97), h2-h3 26 (24-28), h2-h2 40 (38-40).

Epimerites I free. Rudimentary sclerites rEpIIa small, approximately the same size as alveolus of seta la. Humeral shield ventrally fused with epimerites III. Genital apparatus situated between levels of trochanters III, IV, length 46 (45-47), greatest width 17 (17) (Fig. 1C). Small and rounded epiandrum present. Postgenital plaque present, setae $g$ thin, filiform. Adanal apodemes heavily sclerotised, without apophyses. Translobar apodeme present. Setae ps3 inserted on small adanal shields anterolateral to anal suckers. Anal suckers 14 (14-15) in diameter, distance between centers of discs 19 (19-23). Epimerites IVa short. Setae $4 b$ situated anterior to level of setae $3 a$, setae $g$ slightly posterior to $4 a$.

Legs IV with ambulacral disc extending to level of setae h3. Setae $s R$ of trochanters III thick, with hook-shaped apex, 32 (29-32) long. Modified setae $d$ of tarsus IV barrel-shaped, with discoid cap, situated apically; modified setae $e$ hemispheroid, without cap, situated apically (Fig. 3D). Length of solenidia: $\sigma 1$ of genu I 56 (62), $\sigma$ of genu II 14 (14), $\sigma$ of genu III 26 (25-26), $\varphi$ of tibia I 88 (90-97), $\varphi$ of tibia II 94 (100-105), $\varphi$ of tibia III 72 (67-69), $\varphi$ of tibia IV 46 (46-47), $\omega 1$ of tarsus I 22 (22-23), $\omega 3$ of tarsus I 36 (35-40), $\omega 1$ of tarsus II 29 (27-29).

Female [Based on 4 paratypes.] Length of idiosoma from anterior extremity to apices of hyaline lobar processes 541-580, greatest width 244-256. Length of hysterosoma from sejugal furrow to apices of lamellar lobar processes 383-412. Prodorsal shield shaped as in male, 136-139 in length, 168-170 in width, surface as in the male (Fig. 2A). Vertical setae ve represented by alveoli. Setae $s i$ thin needle-like, 25-27 long, separated by 76-80; setae se 174-181 long, separated by 112-117. Humeral shields with setae $c 2$ needle-like, 38-42 long. Setae c3 narrowly lanceolate, with subapical tooth, 30-35 in length. Hysteronotal shield: length from anterior margin to bases of setae $h 3$ 300-313, width at largest part near anterior margin 176-187, lateral margins with incisions at level of trochanters III, DHA absent, surface with ovate lacunae situated between levels of trochanters IV and setae $h l$. Dorsal setae $d l, d 2$ present. Setae $h l$ piliform, 8-10 long, situated antero-mesal to bases of setae $h 2$. Width of opisthosoma at level of setae $h 2$ 79-82. Setae ps 1 positioned dorsally on opisthosomal lobes, closer to bases of $h 3$ than to $h 2$, equidistant from outer and inner margins of lobe. Distance from bases of setae $h 3$ to membranous apices of lobes 82-85. Setae $f 2$ present, minute, situated ventrally near lateral margins of opisthosoma, barely perceptible in some specimens. Supranal concavity open posteriorly into terminal cleft. Length of terminal cleft together with supranal concavity 183-189, width of cleft at level of setae $h 36-8$. Interlobar membrane indistinct. External copulatory tube present, attenuate apically, 56-64 long (Figs. 2A, 3G). Spermatheca as in Figure 3C, secondary spermaducts about 30 long. Distance between levels of dorsal setae and setal pairs: $c 2-d 2$ 54-62, d1-d2 33-40, e1-e2 56-60, e2-h2 68-72, h2-h3 51-52, h2-h2 57-63.

Epimerites I free. Epigynum 56-58 in length, 102-106 in width (Fig. 2B). Epimerites IVa present, short. Setae ps3 situated at posterior level of anal opening. Setae $s R$ of trochanters III thick with large apical hook, 29-33 long.

Legs IV with ambulacral disc extending to level of setae $h 3$. Length of solenidia: $\sigma l$ of genu I 55-65, $\sigma$ of genu II $14-15, \sigma$ of genu III $27-31, \varphi$ of tibia I 88-93, $\varphi$ of tibia II 101-107, $\varphi$ of tibia III 68-71, $\varphi$ of tibia IV $29-32, \omega 1$ of tarsus I 20-24, $\omega 3$ of tarsus I 31-37, $\omega 1$ of tarsus II 21-27.

Remarks

The new species most closely resembles $T$. unciseta Černý \& Lukoschus, 1975 described from Tachyphonus cristatus (Linnaeus) (Thraupidae) in Surinam; both species share the following characters: in both sexes, subhumeral setae $c 3$ have apical tooth and setae $s R$ of trochanters III have a large hook-shaped apex and dorsal hysterosomal appertures (DHA) are absent; in females, the terminal cleft is narrow, setae $h l$ are thin piliform, ovate lacunae are present only on the posterior half of hysteronotal shield, and the external copulatory tube is present; in males, the translobar apodeme is present, and hyaline lobar processes are smooth. The new species can be distinguished from $T$. unciceta in having the following features: in males, epimerites III and IV reach the level of setae $4 b$, and in females, the apical parts of opisthosomal lobes are narrow and gradually tapering distally, and lacunae of 


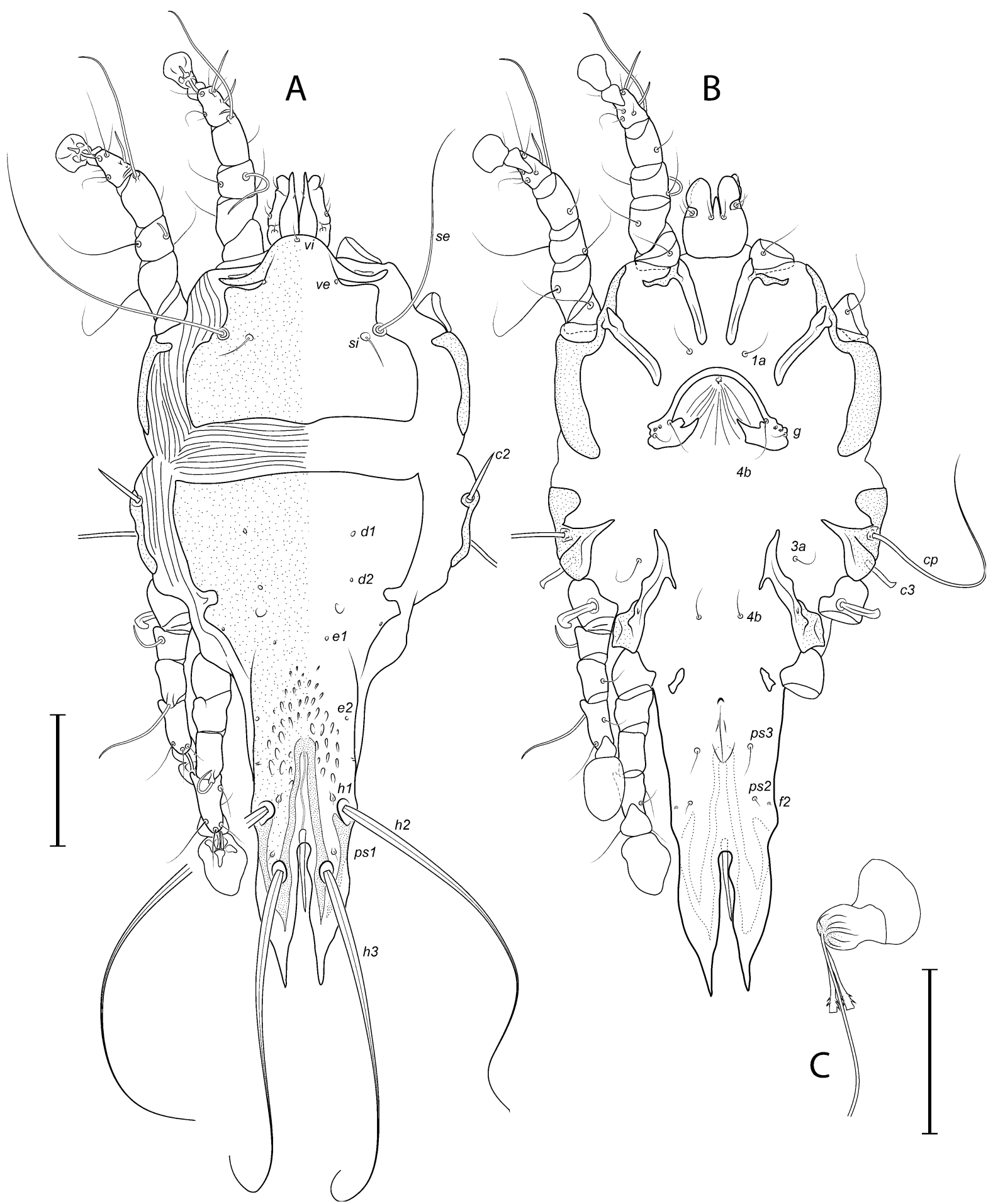

Fig. 2 Trouessartia calcealgiana n. sp. Female. A, Dorsal view; B, Ventral view; C, Spermatheca. Scale-bars: A, B, $100 \mu \mathrm{m}$; C, $50 \mu \mathrm{m}$ 

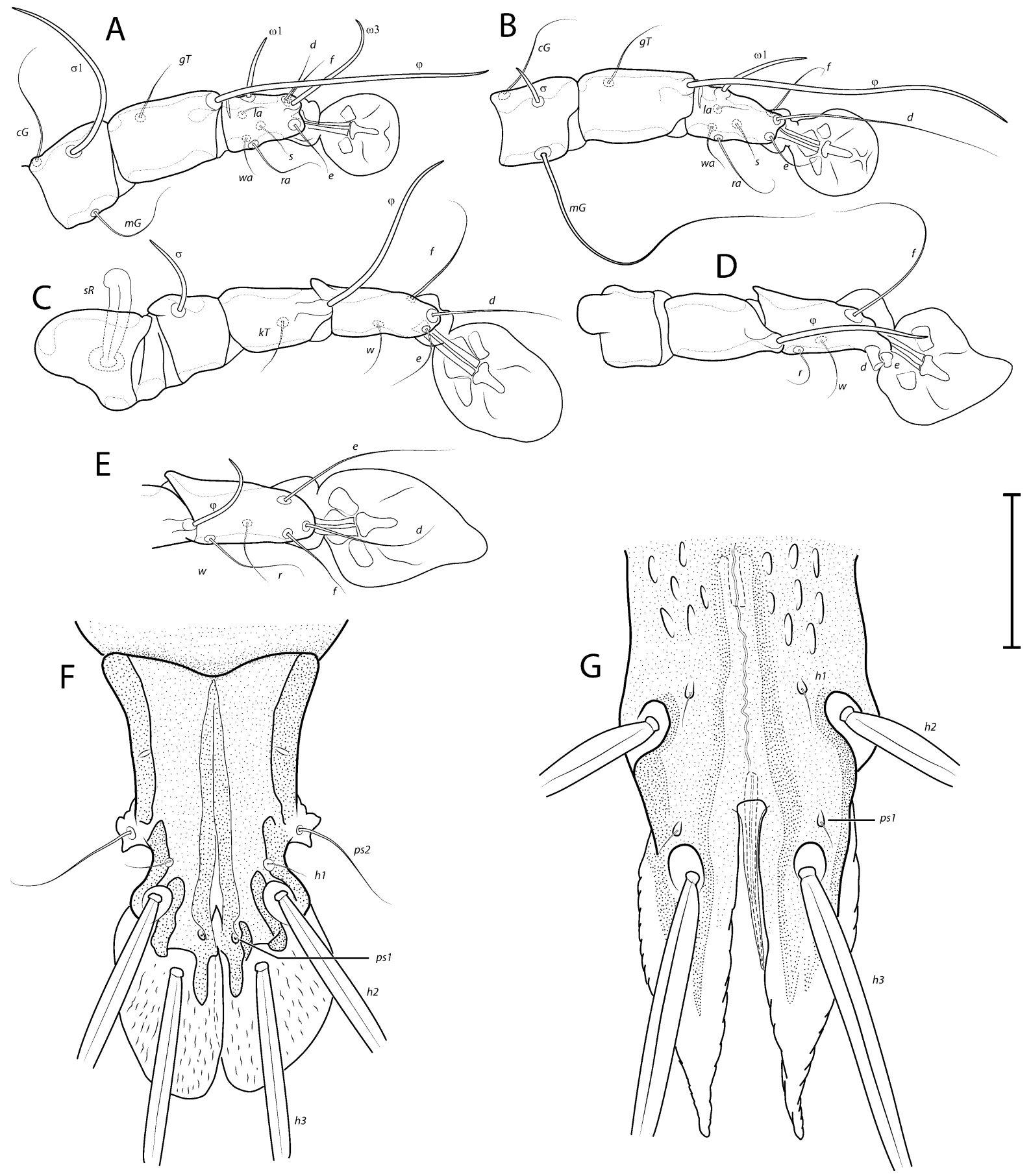

Fig. 3 Trouessartia calcealgiana $\mathrm{n}$. sp. A-D, Male, dorsal view of genua, tibiae and tarsi of legs I-IV; E, Female, dorsal view of distal part of tibia and tarsus IV; F, Male, dorsal view of opisthosoma; G, Female, dorsal view of opisthosoma. Scale-bar: $50 \mu \mathrm{m}$ 
the hysteronotal shield are situated between the levels of setae $e 2$ and $h 1$. In males of T. unciseta, epimerites III and IV do not reach the level of setae $4 b$, and in females, the opisthosomal lobes are swollen immediately anterior to their apices, and lacunae are present between the levels of setae $e l$ and $e 2$.

Trouessartia calcealgiana $\mathrm{n}$. sp. bears superficial similarities with another trouessartiid genus, Calcealges Gaud, 1952, such as subhumeral seta $c 3$ with subapical tooth, ambulacral discs of posterior legs being much larger than those of anterior legs in both sexes, and strongly narrowed and elongated posterior part of opisthosoma in females (Orwig, 1968; Hernandes, 2015).

\section{Trouessartia gigaphallus n. sp.}

Type-host: Tyrannus melancholicus Vieillot (Passeriformes: Tyrannidae).

Type-locality: Barranco Branco, Superagüi National Park, Paraná State, Brazil

Type-material: Holotype male (DZ-UnespRC 3741), 23.xi.1993, coll. M. Arzua (ARM-1650, band \# E25404). Paratypes: 2 males and 7 females (DZUnespRC 3742-3750), same data as for the holotype. Additional material: one female, same host species, 11.XII.2013, coll. F.A. Hernandes Lago Azul, Rio Claro, São Paulo State, Brazil.

ZooBank registration: To comply with the regulations set out in article 8.5 of the amended 2012 version of the International Code of Zoological Nomenclature (ICZN, 2012), details of the new species have been submitted to ZooBank. The Life Science Identifier (LSID) for Trouessartia gigaphallus $\mathrm{n}$. sp. is urn:lsid:zoobank.org:act:D2835E92-481B-4136-8ADC-8E38 CDF57D10.

Etymology: The specific epithet is a contraction of gigas (giant, Gr.) and phallus (penis Gr.), referring to the extraordinarily long genital apparatus of male.

\section{Description (Figs. 4-6, 7D-F)}

Male [Holotype, range for 2 paratypes in parentheses). Length of idiosoma from anterior extremity to bases of setae $h 3571$ (532-565), greatest width of idiosoma at level of humeral shields 259 (235-245). Length of hysterosoma from sejugal furrow to bases of setae $h 3$ 387 (378-395). Prodorsal shield: length along midline 153 (158-159), greatest width of posterior part 165
(169-172), lateral margins at level of trochanters II with shallow concavities, antero-lateral extensions rounded, not extending to bases of epimerites Ia between legs I and II, lateral margins of posterior part not fused with scapular shields, posterior margin straight, surface smooth (Fig. 4A). Vertical setae ve represented by alveoli. Internal scapular setae si thin needle-like, 27 (31) long, separated by 65 (63-70); external scapular setae se 176 (191-199) long, separated by 108 (112-114). Humeral shield with setae $c 2$ thin, 53 (51-53) long. Setae c3 narrowly lanceolate, acute apically, 26 (26-28) long. Prohysteronotal and lobar shields fused. Prohysteronotal shield: length 235 (234-242), width at anterior margin 186 (186-191), lateral margins sinuous, dorsal hysterosomal apertures (DHA) absent, surface smooth. Dorsal setae $d 1, d 2$ present, minute. Setae $f 2$ absent. Length of lobar shield excluding terminal lamellae 105 (105-110). Apical parts of opisthosomal lobes approximate, separated by narrow parallelsided terminal cleft, length of cleft from anterior end to apices of lamellae 45 (45-47), width in anterior part 5 (4-5). Terminal lamellae roughly rectangular with rounded angles, with smooth margins (Fig. 6G), length from bases of setae $h 3$ to lamellar apices 35 (35-37). Setae h2 330 (309-360) long, setae h3 196 (190-198) long. Distance between levels of dorsal setae and setal pairs: $c 2-d 2101$ (94-103), $d 1-d 255$ (57-58), e1-e2 57 (54-58), e2-h2 90 (85-86), h2-h3 24 (23-27), h2-h2 46 (47).

Epimerites I free. Rudimentary sclerites rEpIIa of moderate size, roughly circular, 2-3 times the diameter of setae $1 a$. Humeral shield ventrally fused with epimerites III. Genital apparatus situated between levels of trochanters III and IV, length 124 (125-128), greatest width 28 (30) (Figs. 4B, 6H). Large epiandrum present. Postgenital plaque absent, setae $g$ thin, filiform. Adanal apodemes heavily sclerotised, without apophyses. Translobar apodeme present. Setae ps3 inserted on small adanal shields anterolateral to anal suckers. Anal suckers 21 (19-21) in diameter, distance between centers of discs 30 (30-34). Epimerites IVa wide and long, anterior ends reaching level of setae $4 a$. Setae $4 b$ situated anterior to level of setae $3 a$, setae $g$ and $4 a$ situated approximately at same transverse level.

Legs IV extending by ambulacral disc to level of setae $h 2$. Setae $s R$ of trochanters III short, spiculiform, 15 (15-19) long. Modified seta $d$ of tarsus IV barrel- 


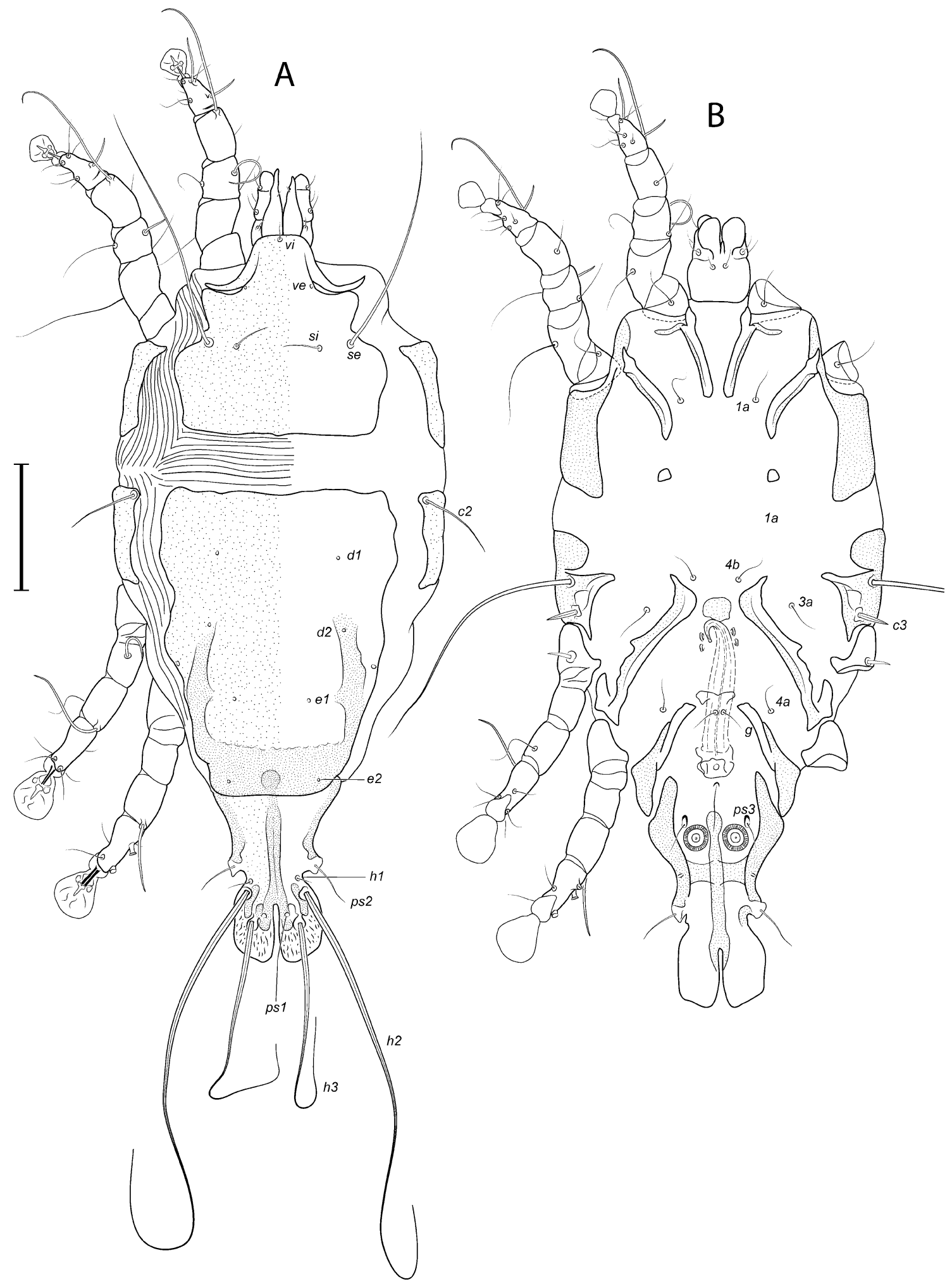

Fig. 4 Trouessartia gigaphallus n. sp. Male. A, Dorsal view; B, Ventral view. Scale-bar: $100 \mu \mathrm{m}$ 
shaped, with discoid cap, situated at basal half of segment; modified seta $e$ hemispheroid, without cap, situated apically; seta $r$ situated ventrally on triangular protuberance (Fig. 6E). Length of solenidia: $\sigma l$ of genu I 55 (54-60), $\sigma$ of genu II 17 (17-18), $\sigma$ of genu III 34 (29-34), $\varphi$ of tibia I 94 (89-92), $\varphi$ of tibia II 102 (96-107), $\varphi$ of tibia III 70 (55-70), $\varphi$ of tibia IV 48 $(47-48), \omega 1$ of tarsus I 26 (26-28), $\omega 3$ of tarsus I 36 (38-41), $\omega 1$ of tarsus II 24 (24-25).

Female [Based on 5 paratypes.] Length of idiosoma from anterior end to apices of hyaline lobar processes 604-663, greatest width 251-270. Length of hysterosoma from sejugal furrow to apices of lamellar lobar processes 431-450. Prodorsal shield: shaped as in male, 166-179 in length, 177-185 in width, surface as in the male (Fig. 5A). Vertical setae ve represented by alveoli. Setae si thin needle-like, 30-34 long, separated by 66-70; setae se 170-182 long, separated by 115-124. Humeral shields with setae $c 2$ needle-like, 53-57 long. Setae $c 3$ narrowly lanceolate, acute apically, 24-30 in length. Hysteronotal shield: length from anterior margin to bases of setae $h 3$ 372-399, width at largest part near anterior margin 186-198, lateral margins sinuous, DHA absent, surface with few oval to circular lacunae between levels of setae $e l$ and $e 2$. Dorsal setae $d 1, d 2$ present. Setae $h l$ thin, piliform, 12-15 long, situated antero-mesal to bases of setae $h 2$. Width of opisthosoma at level of setae h2 110-116. Setae $p s 1$ positioned dorsally on opisthosomal lobes, much closer to bases of $h 3$ than to $h 2$, equidistant from outer and inner margins of lobe. Distance from bases of setae $h 3$ to membranous apices of lobes 47-51. Setae $f 2$ present, minute, situated ventrally near bases of setae $p s 2$, barely perceptible in some specimens. Supranal concavity open posteriorly into terminal cleft. Length of terminal cleft together with supranal concavity 167-189, width of cleft at level of setae $h 3$ 20-37. Interlobar membrane indistinct. External copulatory tube present, small, situated in anterior end of supranal concavity, about 10 long (Fig. 6H). Spermatheca as in Fig. 5C, secondary spermaducts about 20 long. Distance between levels of dorsal setae and setal pairs: $c 2-d 2$ 105-113, $d 1-d 2$ 49-62, e1-e2 48-54, $e 2-h 2$ 86-90, h2-h3 71-73, h2-h2 85-90.

Epimerites I free. Epigynum 56-61 in length, 110-117 in width (Fig. 5B). Epimerites IVa present. Setae $p s 3$ situated posterior to level of anal opening. Setae $s R$ of trochanters III narrowly lanceolate, acute apically, 14-18 long. Legs IV extending by ambulacral disc to level of setae psl. Length of solenidia: $\sigma 1$ of genu I 53-67, $\sigma$ of genu II 17-18, $\sigma$ of genu III $30-38, \varphi$ of tibia I 87-92, $\varphi$ of tibia II $96-114, \varphi$ of tibia III $68-79, \varphi$ of tibia IV 34-38, $\omega 1$ of tarsus I $24-27, \omega 3$ of tarsus I $35-42, \omega 1$ of tarsus II $22-25$.

\section{Remarks}

Trouessartia gigaphallus $\mathrm{n}$. sp. resembles $T$. savanae Hernandes, 2014 described from Tyrannus savana Vieillot (Tyrannidae) in having large and nearly square-shaped epiandrum in males and truncate terminal lamellae. The new species is readily distinguished from $T$. savanae, and also from all members of the genus, by having an extraordinary long male genital apparatus, which extends from the level of setae $c 3$ to the anterior margin of anal opening. In males of $T$. savanae, the genital apparatus is situated between the midlevel of trochanters III and the level of setae $4 a$ and about 2.5 times shorter than that of $T$. gigaphallus. Females of $T$. gigaphallus differ from those of $T$. savanae in having setae $h l$ thin piliform ( $v s$ short spiculiform), external copulatory tube small (about $8 \mu \mathrm{m}$ long $v s$ 17-20 $\mu \mathrm{m}$ long), and the anterior part of the hysteronotal shield is unornamented ( $v s$ ornamented with faint circular lacunae).

\section{Discussion}

Besides only two species reliably reported from woodpeckers (Piciformes: Picidae) (Hernandes, 2014; Mironov \& Bermúdez, 2017), all remaining Trouessartia species are associated only with passerines (Passeriformes) worldwide. Records from other bird groups (e.g. Gruiformes, Charadriiformes, Psittaciformes) have been largely regarded as questionable (Santana, 1976). The genus is the most speciose of the family, currently comprising c.120 species, and the second among all presently recognised genera of feather mites after Proctophyllodes Robin, 1868 (Santana, 1976; Mauri \& De Alzuet, 1968; Černý \& Lukoschus, 1975; Gaud, 1977; Černý, 1979; Mironov, 1983; Gaud \& Atyeo, 1986, 1987; Mironov \& Kopij, 1996, 2000; OConnor et al., 2005; Carleton \& Proctor, 2010; Burdejnaja \& Kivganov, 2011; Mironov \& González-Acuña, 2013; Constantinescu et al. 2013, 2016a, b, 2017; Hernandes, 2014; 


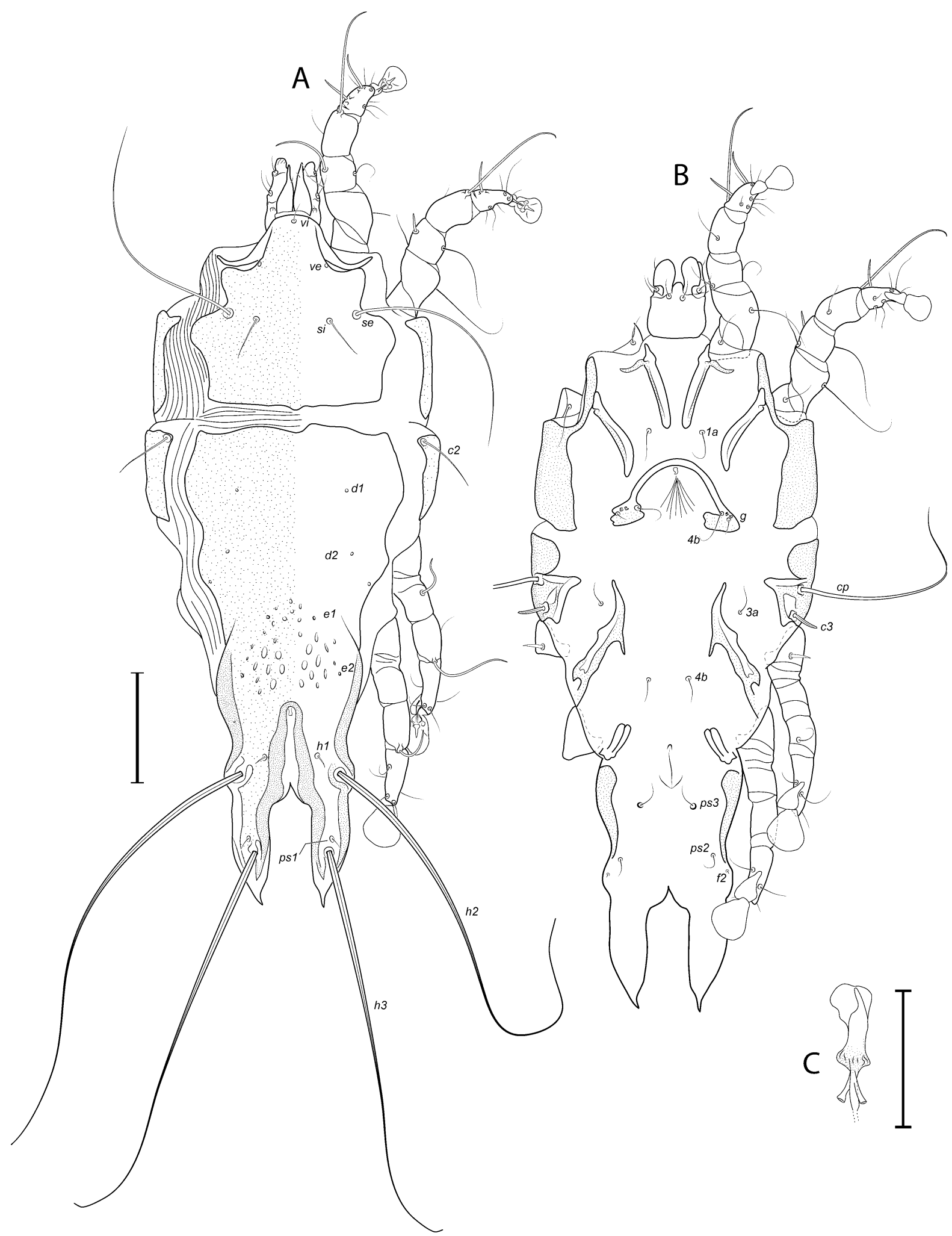

Fig. 5 Trouessartia gigaphallus n. sp. Female. A, Dorsal view; B, Ventral view; C, Spermatheca. Scale-bars: A, B, $100 \mu \mathrm{m}$; C, $50 \mu \mathrm{m}$ 


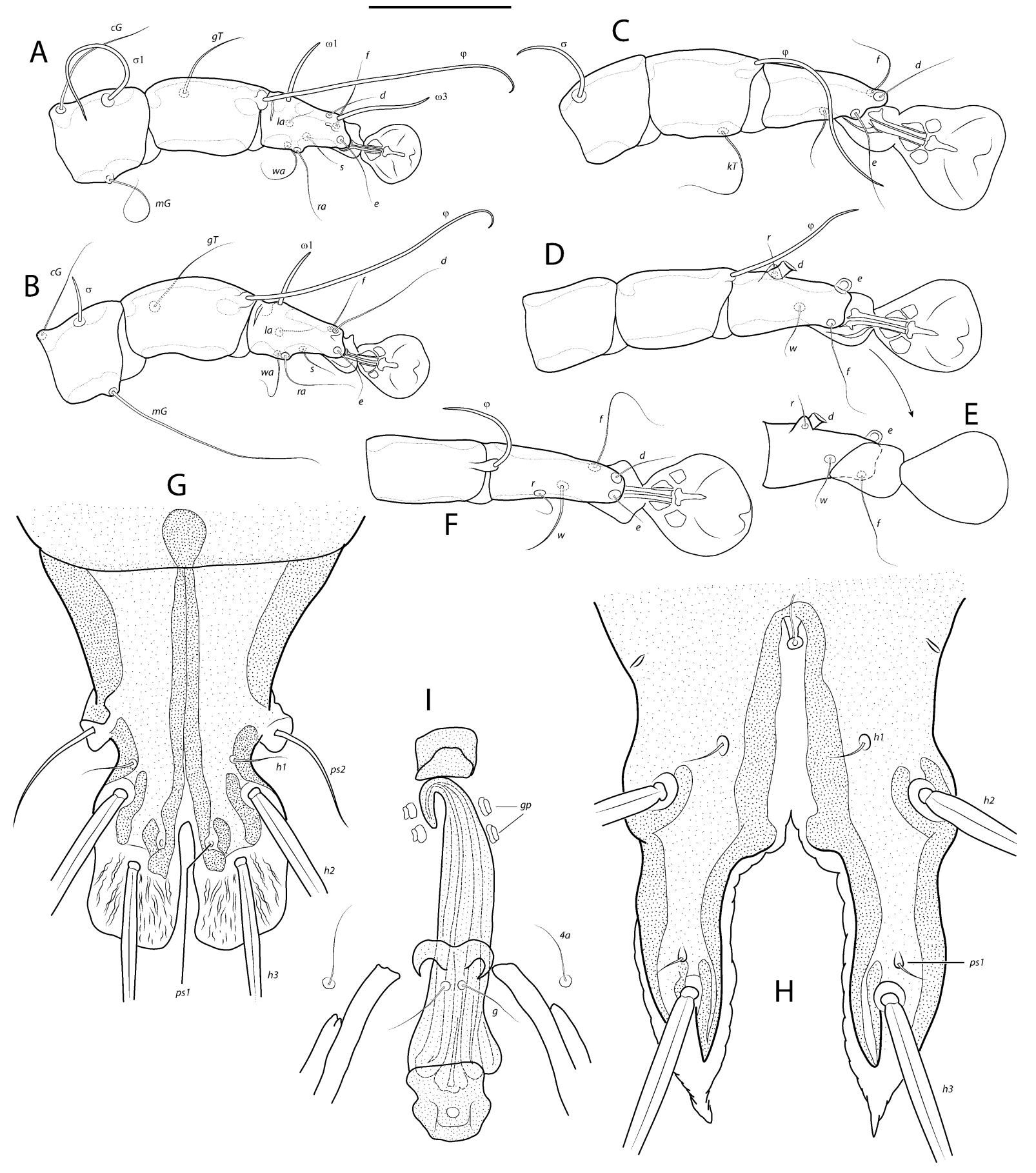

Fig. 6 Trouessartia gigaphallus n. sp. A-D, Male, dorsal view of genua, tibiae and tarsi of legs I-IV; E, Male, ventral view of tarsus IV; F, Female, dorsal view of tibia and tarsus IV; G, Male, dorsal view of opisthosoma; H, Female, dorsal view of opisthosoma; I, Male, ventral view of genital apparatus. Scale-bar: $50 \mu \mathrm{m}$ 

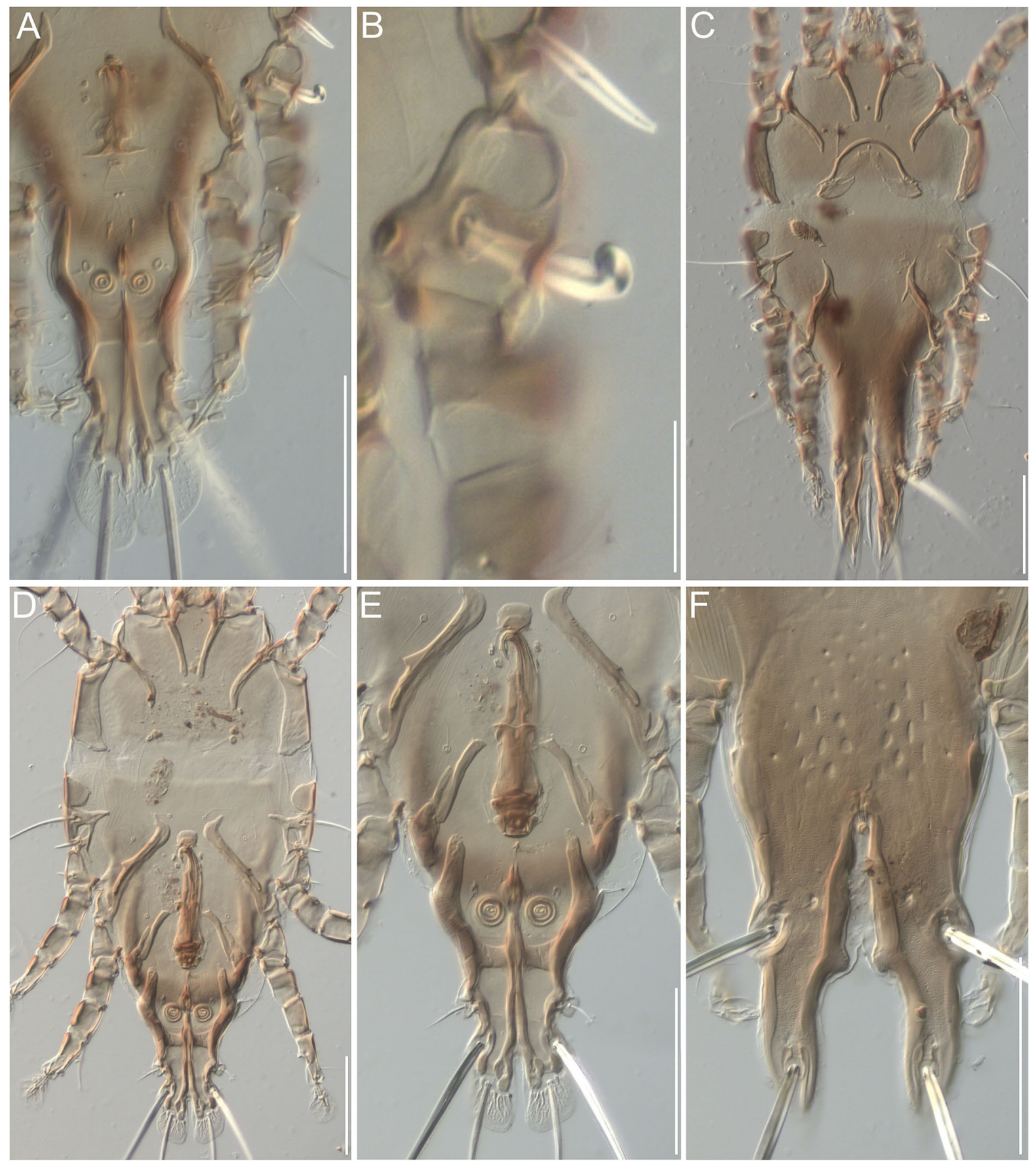

Fig. 7 Photomicrographs of Trouessartia calcealgiana n. sp. (A-C) and T. gigaphallus $\mathrm{n}$. sp. (D-F) taken with differential interference contrast (DIC). A, Male, opisthosoma, ventral view; B, Male, detail of setae $c 3$ and $s R I I I$; C, Female, ventral view; D, Male, idiosoma, ventral view; E, Male, hysterosoma, ventral view; E, Female, hysterosoma, dorsal view. Scale-bars: A, C-F, $100 \mu \mathrm{m}$; B, $25 \mu \mathrm{m}$

Hernandes \& Valim, 2015; Mironov \& Palma, 2016; Mironov \& Overstreet, 2016; Hernandes \& OConnor, 2017; Mironov \& Bermúdez, 2017). Of the 23 species of Trouessartia described from passerines the
Neotropical region, almost two thirds (17) are reported from birds of the suborder Passeri, while only 6 species are known from birds of the suborder Tyranni. 
The present study adds two more species to the list of associates of this latter suborder.

Acknowledgement I thank M. Arzua for collecting both mites described herein.

Funding This study was funded by FAPESP - São Paulo Research Foundation (2011/50145-0).

\section{Compliance with ethical standards}

Conflict of interest The author declares that he has no conflict of interest.

Ethical approval All applicable institutional, national and international guidelines for the care and use of animals were followed.

\section{References}

Atyeo, W. T., \& Gaud, J. (1966). The chaetotaxy of sarcoptiform feather mites (Acarina: Analgoidea). Journal of the Kansas Entomological Society, 39, 337-346.

Atyeo, W. T., \& Peterson, P. C. (1977). Trouessartiidae, new status, with the description of a new genus (Acarina: Analgoidea). Journal of Medical Entomology, 13, 737-741.

Barreto, M., Burbano, M. E., Proctor, H. C., Mironov, S. V., \& Wauthy, G. (2012). Feather mites (Acariformes: Psoroptidia) from Colombia: preliminary list with new records. Zootaxa, 3516, 1-68.

Berla, H. F. (1959a). Analgesoidea Neotropicais. II - Três novas espécies de Trouessartia Canestrini, 1899 (Acarina, Proctophyllodidae), hóspedes de Fringillidae (Aves, Passeriformes). Boletim do Museu Nacional, Nova série, Zoologia, 208, 1-8.

Berla, H. F. (1959b). Analgesoidea Neotropicais. IV - Sôbre algumas espécies novas ou pouco conhecidas de acarinos plumícolas. Boletim do Museu Nacional, Nova série, Zoologia, 209, 1-17.

Berla, H. F. (1960). Analgesoidea Neotropicais. VII - Novas espécies de acarinos plumícolas. Anais da Academia Brasileira de Ciências, 32, 95-105.

Berla, H. F. (1962). Analgesoidea Neotropicais. IX - Uma nova espécie de Trouessartia Canestrini, 1899. Boletim do Museu Nacional, Nova série, Zoologia, 241, 1-5.

Burdejnaja, S. J., \& Kivganov, D. A. (2011). A new species of the genus Trouessartia (Analgoidea, Trouessartiidae) from Ukraine. Vestnik Zoologii, 45, e29-e31.

Carleton, R. E., \& Proctor, H. C. (2010). Feather mites associated with Eastern Bluebirds (Sialia sialis L.) in Georgia, including the description of a new species of Trouessartia (Analgoidea: Trouessartiidae). Southeastern Naturalist, 9, 605-623.

Černý, V. (1979). Feather mites (Sarcoptiformes: Analgoidea) of some warblers from Czechoslovakia. Folia Parasitologica, 26, 81-84.
Černý, V., \& Lukoschus, F. S. (1975). Parasitic mites of Surinam XXXIII. Feather mites (Analgoidea). Studies on the Fauna of Suriname and other Guyanas, 58, 184-203.

Constantinescu, I. C., Chişamera, G., Pocora, V., Stanciu, C., \& Adam, C. (2013). Two new species of feather mites (Acarina: Analgoidea) from the Moustached Warbler, Acrocephalus melanopogon (Passeriformes, Acrocephalidae) in Romania. Zootaxa, 3709, 267-276.

Constantinescu, I. C., Cobzaru, I., Mukhim, D. K. B., \& Adam, C. (2016a). Two new species of the genus Trouessartia (Acari, Trouessartiidae) from leiothrichid birds (Aves, Leiothrichidae). ZooKeys, 571, 59-79.

Constantinescu, I. C., Cobzaru, I., Mukhim, D. K. B., \& Adam, C. (2016b). Two new species of the feather mite genus Trouessartia (Acari: Trouessartiidae) from Asia. Zootaxa, 4137, 357-374.

Constantinescu, I. C., Cobzaru, I., Geamana, N. A., Mukhim, D. K. B., \& Adam, C. (2017). Two new species of feather mites (Acarina: Psoroptidia) from the blue-throated blue flycatcher, Cyornis rubeculoides (Passeriformes: Muscicapidae). Journal of Natural History, 51, 277-297.

Gaud, J. (1952). Sarcoptides plumicoles des oiseaux de Madagascar. Mémoirs de l'Institut Scientifique de Madagascar, Série A, 7, 81-107.

Gaud, J. (1977). La faune terrestre de l'Île de Sainte Hélène. 4.3. Acariens Sarcoptiformes Plumicoles parasites d'oiseaux. Annales du Musée Royale de l'Afrique Centrale, série in8o. Sciences Zoologiques, 220, 260-269.

Gaud, J., \& Atyeo, W. T. (1986). Les Trouessartia (Analgoidea, Trouessartiidae) parasites des hirondelles de l'Ancien Monde. I. Le Groupe appendiculata. Acarologia, 27, 263-274.

Gaud, J., \& Atyeo, W. T. (1987). Les Trouessartia (Analgoidea, Trouessartiidae) parasites des hirondelles de l'Ancien Monde. I. Le Groupe minutipes. Acarologia, 28, 367-379.

Gaud, J., \& Atyeo, W. T. (1996). Feather mites of the World (Acarina, Astigmata): the supraspecific taxa. Annales $d u$ Musée Royale de l'Afrique Centrale, Sciences Zoologiques, 277, 1-193 (Pt. 1, text), 1-436 (Pt. 2, illustrations).

Griffiths, D. A., Atyeo, W. T., Norton, R. A., \& Lynch, C. A. (1990). The idiosomal chaetotaxy of astigmatid mites. Journal of Zoology, 220, 1-32.

Hernandes, F. A. (2014). Five new species of the feather mite genus Trouessartia Canestrini from South America (Acari: Trouessartiidae). Zootaxa, 3856, 50-72.

Hernandes, F. A. (2015). Two new feather mites of the genus Calcealges Gaud, 1952 (Acari: Trouessartiidae) from antbirds (Passeriformes: Thamnophilidae) in Brazil. Systematic Parasitology, 91, 241-252.

Hernandes, F. A., \& OConnor, B. M. (2017). Out of Africa: the feather mites (Acariformes) of the common waxbill, Estrilda astrild (Linnaeus, 1758) (Passeriformes: Estrildidae) from Brazil. Parasites \& Vectors, 10, 299.

Hernandes, F. A., \& Valim, M. P. (2015). A new species of the genus Trouessartia Canestrini (Acari: Trouessartiidae) from Neotropical passerines (Aves: Tyrannidae). International Journal of Acarology, 41, 382-388.

ICZN (2012). International Commission on Zoological Nomenclature: Amendment of articles 8, 9, 10, 21 and 78 of the International Code of Zoological Nomenclature to 
expand and refine methods of publication. Bulletin of

Zoological Nomenclature, 69, 161-169.

Kanegae, M. F., Valim, M. P., Fonseca, M. A., Marini, M. A., \& Serra-Freire, N. M. (2008). Ácaros plumícolas (Acari: Astigmata) em aves do Cerrado do Distrito Federal, Brasil. Biota Neotropica, 8, 30-38.

Krantz, G. W., \& Walter, D. E. (2009). A manual of acarology. 3rd ed. Lubbock, USA: Texas Tech University Press, 807 pp.

Mauri, R., \& De Alzuet, A. B. (1968). Una nueva espécie de Trouessartia Canestrini, 1899 (Acarina: Proctophyllodidae). Revista del Museo de La Plata, nueva serie, Zoología, 85, 169-172.

Mironov, S. V. (1983). [Feather mites of the genus Trouessartia of the USSR fauna and descriptions of new species (Analgoidea)]. Parazitologiya, 17, 361-369. (In Russian).

Mironov, S. V., \& Bermúdez, S. (2017). Feather mites (Acariformes: Analgoidea) associated with the hairy woodpecker Leuconotopicus villosus (Piciformes: Picidae) in Panama. Acarologia, 57, 941-955.

Mironov, S. V., \& González-Acuña, D. A. (2013). A new feather mite species of the genus Trouessartia Canestrini, 1899 (Acariformes: Trouessartiidae) from the White-crested Elaenia Elaenia albiceps (D’Orbigny \& Lafresnaye) (Passeriformes: Tyrannidae) in Chile. Acarina, 21, 123-132.

Mironov, S. V., \& Kopij, G. (1996). New feather mite species (Acarina: Analgoidea) from some starlings (Passeriformes: Sturnidae) of South Africa. Journal of African Zoology, 110, 257-269.

Mironov, S. V., \& Kopij, G. (2000). New feather mites species of the genus Trouessartia (Acari: Analgoidea:
Trouessartiidae) from South African passerines (Aves: Passeriformes). Mitteilungen aus dem Hamburgischen Museum and Institut, 97, 99-115.

Mironov, S. V., \& Overstreet, R. M. (2016). A new feather mite species of the genus Trouessartia Canestrini (Acariformes: Trouessartiidae) from the Northern rough-winged swallow Stelgidopteryx serripennis (Passeriformes: Hirundinidae) in Pennsylvania. Acarina, 24, 3-9.

Mironov, S. V., \& Palma, R. L. (2016). A new feather mite of the genus Trouessartia Canestrini 1899 (Acariformes: Trouessartiidae) from the Seychelles magpie-robin, Copsychus sechellarum (Passeriformes: Muscicapidae). Acta Parasitologica, 61, 629-635.

Norton, R. A. (1998). Morphological evidence for the evolutionary origin of Astigmata (Acari: Acariformes). Experimental \& Applied Acarology, 22, 559-594.

OConnor, B. M., Foufopoulos, J., Lipton, D., \& Lindström, K. (2005). Mites associated with the small ground finch, Geospiza fuliginosa (Passeriformes: Emberizidae), from the Galápagos Islands. Journal of Parasitology, 91, 1304-1313.

Orwig, K. R. (1968). The genera and species of the feather mite subfamily Trouessartinae except Trouessartia (Acarina: Proctophyllodidae). Bulletin of the University of Nebraska State Museum, 8, 1-187.

Santana, F. J. (1976). A review of the genus Trouessartia: (Analgoidea: Alloptidae). Journal of Medical Entomology, $1,1-28$.

Valim, M. P., Hernandes, F. A., \& Proctor, H. C. (2011). Feather mites of Brazil (Acari: Astigmata: Analgoidea and Pterolichoidea). International Journal of Acarology, 37, 293-324. 